American Journal of Pediatrics
2021; 7(2): $68-71$
http://www.sciencepublishinggroup.com/j/ajp
doi: $10.11648 /$ j.ajp.20210702.16
ISSN: $2472-0887$ (Print); ISSN: $2472-0909$ (Online)

\title{
The Mixed Bacterial-viral Intestinal Infections in Children of Early Age
}

\author{
Zemfira Mekhtiyevna Kuliyeva ${ }^{1}$, Lala Islakhovna Rustamova ${ }^{2}$, Fatma Vagifovna Qilindjova ${ }^{1}$, \\ Matanat Nabiyevna Mamedova ${ }^{4}$, Mehriban Musayevna Isayeva ${ }^{3}$, Rena Mammadovna Akhundova ${ }^{3}$ \\ ${ }^{1}$ The Department of Pediatry, The Azerbaijan State Advanced Training Institute for Doctors Named After A. Aliyev, Baku, Azerbaijan \\ ${ }^{2}$ The Department of Virulogy, The Scientific - Research Institute of Medical Prophylaxis NAMED after V. Y. Akhundov, Baku, Azerbaijan \\ ${ }^{3}$ The Biolocical Faculti, "Odlar Yurdu” University, Baku, Azerbaijan \\ ${ }^{4}$ The Department of Infectious Deseases, Azerbaijan Medical University, Baku, Azerbaijan
}

Email address:

lala.rustamova.1967@mail.ru(L. I. Rustamova)

\section{To cite this article:}

Zemfira Mekhtiyevna Kuliyeva, Lala Islakhovna Rustamova, Fatma Vagifovna Qilindjova, Matanat Nabiyevna Mamedova, Mehriban Musayevna Isayeva, Rena Mammadovna Akhundova. The Mixed Bacterial-viral Intestinal Infections in Children of Early Age. American Journal of Pediatrics. Vol. 7, No. 2, 2021, pp. 68-71. doi: 10.11648/j.ajp.20210702.16

Received: March 13, 2021; Accepted: April 19, 2021; Published: May 8, 2021

\begin{abstract}
The aim of investigation to study the of some clinico-microbiological characterisrics of mixed intestinal infections in children of early age. Material and methods - the children under the age of 3 (infants and children), hospitalized in the Children’s Clinical Hospitals № 1 and 7 in Baku for the 2019 year have been examined. Bacteriological and serological studies were carried out to diagnose intestinal infections on the day of admission to hospital feces of sick children were take as material for analyses. Totally the 117 children have been observed. To convirm the diagnosis of bacterial intestinal infection feces were cultured with subsequent detection of sensitivity to antibiotics and for viral intestinal infection, immunochromatografic test was used. The bacteriological and serological investigations were arried out in the ScientificResearch Institute of Medical Prophylaxis named after V. Y. Akhundov during 2019 year. Results - As a result of our studies, 33,3\% (39) of children had mixed infection: a combination of viruses, particularly rotaviruses with St.aureus, E.Coli and C.albicans. From observing children 25 were under 6 month (21,4\%), 15 - 7-12 month (12,8\%), 77 - 1-3 years (65,8\%). The combination of rotaviruses with other viruses (adenovirus and astrovrus) were the most frequently observed ones $(5,1 \pm 2,0 \%$ and $6,8 \pm 2,3 \%$ accordingly) ( $\mathrm{p}=0,167 ; \mathrm{p}=0,067)$. Among opportunistic microbes the S.albicans was a leader. (In $18(15,4 \%)$ patients). C.albicans was with rotavirus $(p=0,063)$, in $5(4,3 \pm 1,9 \%)$ with St.aureus and rotavirus $(p=0,118)$ and in $4(3,4 \pm 1,7 \%)$ with rotavirus and E.Coli $(\mathrm{p}=0,056)$. The viral intestinal infection with 2 associates occured in $5(4,3 \pm 1,9 \%)$ of patients rotavirus + St.aureus + C.albicans and rotavirus + E.Coli + C.albicans $(p=0,056)$.
\end{abstract}

Keywords: The Mix Viral - Bacterial Intestinal Infection, Rotavirus, Adenovirus, Astrovirus, Opportunistic Microflora

\section{Introduction}

The problem of mixed bacterial intestinal infections in children of early age attracts special attention, as they are characterized by a severe course 2 high lethality. Nowadays one to achievements in the study of etiology of acute intestinal infections (AIII), discovery of new causative agents and improvement of their diagnostics is still an actual problem of mixed intestinal infections [1-4].

Differences in frequency of revealing mixed forms of the disease are related to the lack of precise criteria for diagnosing mixed infection and identifying the etiological role of each of the agents in illness genesis [5].

An increase of the role of mixed infections reflects really existing process of microecological relationships. At the modern stage of development of bacteriological and virological diagnostics, it became possible to detect in one sample of feces 2-3 pathogenic causative agents of intestinal infections, which gives possibility to refer such forms of diseases to mixed types [1-3, 6-8].

Lately, AIII occurs in children as mixed infections, caused by virus - viral and viral - bacterial associations, that requires 
the study of them for modern diagnostics and administrations of adequate treatment [8-10]. İn literature of last years, data on the increase of mixed infections appeared: rotavirusbacterial and combination with other viral infections. The presence of mixed infections can considerably change clinical picture, which is specifis for each infection separately and which causes more severe course of disease in children. At present more and more publications appear about increased role of rotavirus in the structure of mixed intestinal infections and the influence of rotavirus on development of diarrhea, occured in children at in - patient departments. Associative virus - bacterial diseases are a group of infections in which a pathological process causes 2 or more agents of viral and bacterial nature [11-15].

In connection with the foregoing, the purpose of this research was to study the characteristics of mixed intestinal infections in children of early age.

\section{Material and Methods}

The type of investigation is the clinico-experimental.

The childern under the age of 3 (infants and children), hospitalized to the Children’s Clinical Hospitals № 1 and 7 in Baku for the 2019 year, have been examined. Bacteriological and serological studies were carried out to diagnose intestinal infections on the day of admission to hospital feces of sick children were take as material for analyses. Totally the 117 children have been observed. To confirm the diagnosis of bacterial intestinal infection feces were cultured with subsequent detection of sensitivity to antibiotics and for viral intestinal infections, immunochromatografic test was used. The bacteriological and serological investigations were carried out in the Scientific-Research Institute of Medical Prophylaxis named after V. Y. Akhundov during 2019 year.

The statistical analyses of given data were carried out by using the alquantity dispers analyses with marking of statistical significance by Fisher.

\section{Results}

As o result of our studies, 35,9\% (42) of children had mixed infection: a combination of viruses, particularly rotaviruses, with Staphylococcus aureus (St.aureus), E.Coli and C.albicans. From observing children 25 were under 6 months $(21,4 \%), 15-7-12$ months $(12,8 \%), 77-1-3$ years $(65,8 \%)$. The combination of rotaviruses with other viruses (adenovirus, astrovirus) and opportunistic microbes (OM) were the most frequently observed ones. Complex clinico epidemiological, serological and bacteriological examinations of sick children with intestinal infections were carried out on the backgrount of AIII in clinical diagnosis. Sick children were divided into 3 groups due to the type of pathogen: virus +virus, $\mathrm{OM}+$ virus and $\mathrm{OM}+$ virus+virus. İn bacteriological study mixed - viral intestinal infection was in combination with in $5(4,3 \pm 1,9 \%)$ children: rotavirus+adenovirus $(\mathrm{p}=0,164)$, in $5(4,3 \pm 1,9 \%)$ children with rotavirus +astrovirus $(p=0,002)$, in $5 \quad(4,3 \pm 1,9 \%)$ adenovirus + astrovirus $(\mathrm{p}=0,164)$ and in $18(15,4 \%)$ rotavirus + OM.

Among intestinal bacterias, C.albicans was a leader, among viruses- rotavirus, in $32(27,4 \pm 4,1 \%)$ patients was with rotavirus $(\mathrm{p}=0,035)$, in $22(18,8 \pm 3,6 \%)$ with adenovirus $(\mathrm{p}=0,301)$, in $15(12,8 \pm 3,1 \%)$ - with astrovirus $(\mathrm{p}=0,273)$. In $9(7,7 \pm 2,5 \%)$ patients rotavirus inffection was combined with C.albicans $(\mathrm{p}=0,063)$. However, viral intestinal infection with 2 associates occured in $5(4,3 \pm 1,9 \%)$ of patients rotavirus + St.aureus + C.albicans $(p=0,118)$, in $4(3,4 \pm 1,7 \%)-$ rotavirus + E.Coli + C.albicans $(\mathrm{p}=0,056)$.

Depending on the period of out patient treatment, duration of diarrhea and treatment in the hospital turned out to be more prolonged as compared with patients with infection of bacterial and viral etiology. The analysis of outpatient treatment showed that the therapy, prescribed at the prehospital stage was inadequate and ineffective, that is evidenced by the positive correlation between the duration of outpatient treatment and intestinal dysfrenction. ( $\mathrm{r}=039 ; \mathrm{p}<$ $0,05)$ and frequency of stool $(\mathrm{r}=038 ; \mathrm{p}<0,05)$. The longer the patients received antibacterial drugs, in particular antibiotics, which shouldn't be prescribed for viral diarrhea, the longer the intestinal dyspenction persisted. İ 86 (78,3\%) patients the duration of the discase varied from 1 to 10 day. The average inpatient stay was longer $(14,9 \pm 0,6$ days $)$ in comparison with patients with bacterial $(13,7 \pm 0,6$ days $)$ and viral $(12,5 \pm 0,8$ days $)$ pathology.

The condition was assessed as agonal in 10 hospitalized children, extremely severe in 67 , very severe in 28 and severe in 12 . It should be noted that combination of microbial associates $(>2,3)$ in this pathology influenced on severity of patients condition in $66,39 \%$ of cases unlike the patients with bacterial and viral pathology.

Such severe condition in mixed infections developed mostly in chidren at the age of $1-33(39,49 \%)$ then in children of the first half of the life $(25,2 \%)$ and in infants from 6 months to 1 year $(26,8)$.

In analysis of clinical manifestations in different groups of mixed infections it was established that hyperthermia (in the range of $39-40^{\circ} \mathrm{C}$ ) was marked in the group of children $(67,0 \%)$ with $\mathrm{OM}+$ virus, diarrhea from 5 to 10 times a day and more than $91,0 \%$ of cases - in group with virus+virus, vomiting from 3 to 5 times a day and more in $72,0 \%$ of cases - in the group $\mathrm{OM}+$ virus and particularly marked intoxication was in the group with OM+virus in $97,0 \%$ of cases. While the duration of hyperthermia was $5,4 \pm 0,2$ days, diarrhea $5,2 \pm 0,3$, vomiting $-2,5 \pm 0,1$, intoxication - $6,2 \pm 0,4$ days.

\section{Discussion}

Analysis of clinical symptoms duration of viral and bacterial intestinal infections testifies more prolongecl temperature reaction $(p=0,05)$ and diaarhea $(p=0,05)$ in comparison with AIII of viral and bacterial etiology. İt is certainly associated with simultaneous exposure of viral and bacterial agents, the development of possible complications (dysbacteriosis of the bowels) which further prolong the 
period of preservation of the above mentioned symptoms.

The symptom of diarrhea had particular features, depending on the properties of associates, which cause mixed intestinal infection.

Feces in this pathology are different from the ones in bacterial and viral intestinal infections. İn mixed intestinal infections, when one of the etiological factors was OM (St.aureus, E.Coli, C.albicans), characteristic lesions were observed not only in small, but in large intestine as well; bloating, rumbling along the bowel, enlargement of the liver.

In our studies, watery stool, a large amount of mucus, «greens», leucocytes, vegetable fiber, neutral fats, stard< sometimes erythrocytes were noted in the copragram. In the total blood test, modurate leucocytosis with neutrophilosis was more often detected. İn combination with accompanying diseases a different picture is observed - leucocytosis with a shift, increase in ESR.

In foreign literatura we can find data about detecting 2 or more AII agents simoultaneously in patients' feces, sometimes with an increase in specific antibodies', titers during serological studies. Nowadays there is no doubt about the imrortance of studying the problem of mixed intestinal infections in children, the prevalence of which (according to different sources) makes up from $7,3 \%$ to $70 \%$ [1-4].

In literature of last years, data on the increase of mixed infections appeared: rotavirus-bacterial and combination with other viral infections. The presence of mixed infections can considerably change clinical picture, which is specifis for each infection separately and which causes more severe course of disease in children. At present more and more publications appear about increased role of rotavirus in the structure of mixed intestinal infections and the influence of rotavirus on development of diarrhea, occured in children at in - patient departments. Associative virus - bacterial diseases are a group of infections in which a pathological process causes 2 or more agents of viral and bacterial nature [10-14].

Thus the clinical course of mixed - viral - bacterial intestinal infections in children of early age differs from that one in viral and bacterial intestinal infections: involvement of 2 or more associates of viral-bacterial agents affects the severity of the disease, the duration of the temperature reaction and diarrhea. The feature of the clinical picture of the viral - bacterial infection was the presence of the complex symptoms which are inherent in both infections: marked signs of intoxication, inflammatory changes, in the mucus membrane of the small and large intestine, retardation in recovery.

It is possible that viral intestinal infection changes the susceptibility of the organism to a conditionally pathologic infection (opportunistic infection) and promotes the activation of endogenous infection.

\section{Conclusions}

1. It was determined that hyperthermia (in the range of 39$40^{\circ} \mathrm{C}$ ) was marked in the group of children $(67,0 \%)$ with opportunistic microb + virus, diarrhea from 5-10 times a day and more than $91,0 \%$ of cases - in croup with virus + virus, vomiting from 3 to 5 times a day and more in $72,0 \%$ of cases - in the group opportunistic microb + virus and particularly marked intoxication was in the group with opportunistic microb + virus in $97,0 \%$ of cases.

2. While the duration of hyperthermia was $5,4 \pm 0,2$ days, diarrhea - 5,2 \pm 0.3 , vomiting $-2,5 \pm 0,1$, intoxication $6,2 \pm 0,4$ days.

3. Analysis of clinical symptoms duration of viral and bacterial intestinal infections testifies more prolonged temperature reaction and diarrhea in comparison with acute intestinal infections of viral and bacterial etiologies.

\section{Funding}

No financial support has been provided for this work.

\section{Conflict of Interests}

Authors declare about absence of conflicts of interests.

\section{Authors' Contributions}

Author 1 and author 2 - head of work, writing and correction of the article, author 3 and author 4 - collection of materiaks and analysing them; author 5 and author $6-$ the statistical analysing of given results of work.

\section{References}

[1] Litvinchuk O. A., Konovalova T. A., Podkolzin A. T. Nosocomial intestinal infections in the infectious departments of children's hospitals. Molecular Diagnostics. 2014; 2 (12): 413-415. (InRuss)

[2] Luk'janova A. M., Behtereva M. K., Ptichnikova N. N. Clinical and epidemiological characteristics of viral diarrhea in children. Journal of Infectology. 2014; 6 (1): 60-66. (In Russ)

[3] Romancov M. G., Smagina A. N. Viral and bacterial infections in children. St. Petersburg. 2011; 137. (In Russ)

[4] Usenko D. V., Ploskireva A. A., Gorelov A. V. Acute intestinal infections in children in the practice of a pediatrician: diagnostic possibilities and issues of modern pediatrics. 2014; 13: 12-20. (In Russ)

[5] Kuliyeva Z. M. The characteristics of mixed intestinal infections in children of early age wth emergency conditions. Rossiisskii meditsinskii zhurnal, 2015; 21 (4): 21-23 (In Russ)

[6] Hnykov A. M., Skvorcova V. V., Semenov V. M. Kinical features of adenoviral infection in children. Vestnik VGMU. 2011; 10 (2): 97-102. (In Russ)

[7] Lanata C., Walker C., Olascoaga A. et al. Global causes of diarrheal disease mortality in children $<$ years of age: a systematic review. PloS one. 2013; 8 (9): 727-788. 
[8] Akimkin V. G., Gorelov A. V., Podkolzin A. T., Denisjuk N. B. Epidemiological and molecular genetic monitoring of rotavirus infection in the Orenburg region in the prevaccination period // Journal Mikrobiologiya, Epidemiology and Immunobiology. 2019; 2: 30-36. (In Russ)

[9] Zajceva E. V., Ol'neva T. A., Kjaleshov K. V. i dr. Monitoring results of antigenic types of rotaviruses of group $\mathrm{A}$ in the territory of the Russian Federation in the period 2011-2015. Clinical laboratory diagnostics. 2016; 61 (7), 445-448. (In Russ)

[10] Majanskij N. A., Majanskij A. N., Kulichenko T. V. Rotavirus infection: Epidemiology, pathology, vaccine prophylaxis // Bulletin of the Academy of Medical Sciences. 2015; 1: 47-55. (In Russ)
[11] Bosch A., Pinto R., Guix S. Human astroviruses, clinical microbiology, review. 2014; 27 (4): 1048-1074.

[12] Ghebremedhim B. Human adenovirus: Viral pathogen with increasing important. Eur. J. Microbiol. Immunol. 2014; 4 (1): 26-33.

[13] Mandal S., Mandal M. Is Rotavirus gastroenteritis a global emerging // Re-emerg. probl. Franse. Med. 2014; 4 (43): 1025-2161.

[14] Olortejui M., Rouhani S., Yori P. et al. Astrovirus infection and diarrhea in 8 countries. Pediatrics. 2018; 14 (1): 20172032.

[15] William M., Marcilio J., Jansen de A. et al. Discovery of novel astrovirus and calicivirus identified in Brazil. Scientific reports. 2019; 9: 55-56. 